found in the space between the female and the cyst wall.

Through the kindness of Dr. R. S. Clark and Prof. Edward Hindle, I have had the opportunity of reexamining cysts of Sarcotaces arcticus found in blue ling landed at Aberdeen, and found what seems to be the male form of this parasite.

A total of twenty-six cysts was examined, all of which contained ova and nauplii in addition to the adult female, and in nineteen of them a hitherto undescribed stage was found, shown in Figs. I and 2. The numbers present in each cyst varied from one to four; they were always found attached to the cyst wall by their ventral surfaces. Their dimensions never exceeded $3 \mathrm{~mm}$. in length, exclusive of the caudal furca, $0.6 \mathrm{~mm}$, in breadth, and $0.2 \mathrm{~mm}$. in thickness. The anterior part is expanded to form a triangle, ending in a small head (Fig. 2). Slight constrictions seem to indicate segmentation, and there are a number of pairs of vestigial appendages. The head bears four pairs of appendages, antennules, antennæ, mandibles and postoral appendages which may be small maxillules or maxillæ.

The ventral surface of the expanded triangular part of the trunk bears two pairs of biramous ap. pendages, and along the length of the body are one or two pairs of hook-like appendages. The telson bears a caudal furca, which is very variable in size.

The mouth leads directly into the alimentary sac, which like that of the female ends blindly and contains a dense black substance probably derived from the blood pigments of the host. Behind the gut are

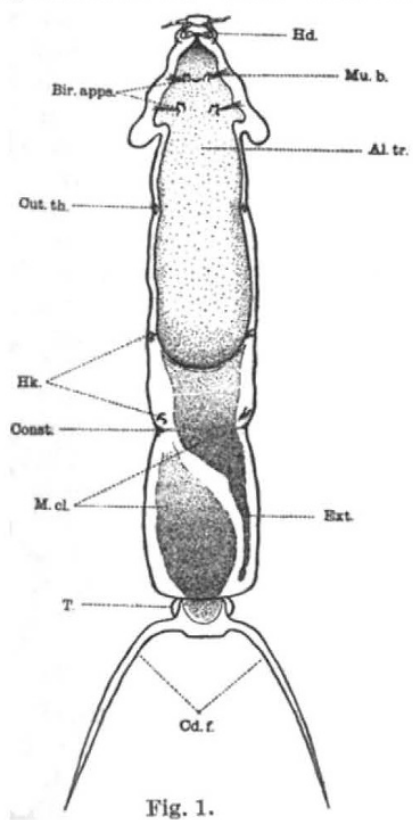

Fig. 1.

VENTRAI ASPECT OF SMALL PARASTTE FROM CYST OF $S$. arcticus. Al.tr., alimentary tract ; Bir. apps., biramous appendages : Cd.f. caudal furca ; Cut. th., euticular thickenings ; Const., constriction of trunk ; Hd., "head"; Hk., hooks; M.cl., cell masses (testes?); Mu. b., muscle band; 'T. telson; Ext., posterior extension of cell mass.

two masses of densely staining tissue suggesting testes, but the material was not sufficiently well preserved to identify the nature of the cells. Although there was a suggestion of a genital duct leading from these organs, no external aperture could be detected.

There can be no reasonable doubt that these parasites represent a stage in the life-cycle of Sar- cotaces. It is very unlikely that they are the progeny of the large individual, and on the evidence are most likely to be males. Komai claimed to have identified testes as well as ova in large individuals of $S$. pacificus, but this statement is open to question in view of the absence of hermaphroditism in all known Copepods.

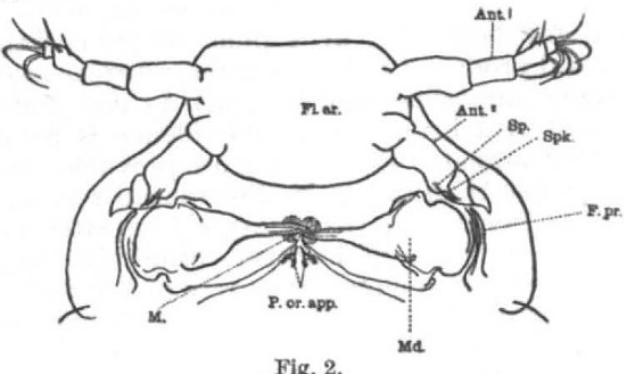

VENTRAT ASPECT OF HEAD.

Ant. ${ }^{1}$, antennule ; Ant. ${ }^{2}$, antenna ; Fl. ar. frontal area ; F. pr., falciform process ; M., mouth-opening ; Md., mandible; P. or app., postoral appendäges ; Spk., spike-like process ; Sp., spine.

The stage of $S$. arcticus described above suggests that this species belongs to the Copepoda and, in view of its form would seem to be most closely related to the family Philichthyidæ.

Department of Zoology,

A. Artmen.

University, Glasgow. July 17.

3 Calman, W. T., "A Treatise on Zoology", Part 7, Appendiculata (A. and C. Black, London, 1909)

${ }^{2}$ Collett, Forh. ved de skand., 11 Mode i Kjobenhavn (1874).

- Hjort, J., Skr. Vidensk. Selsk., Christ., 1 Math. nat. Kl., No. 2 (1895).

- Komai, T., Mem. Coll. Sci. Kyoto., B, 1, No. 3 (1924).

s Olsson, quoted by Hjort, loc. cit.

\section{Preservation of Historic Machines and Apparatus}

Care to ensure that nothing of permanent documentary value should be allowed to go to salvage during the present drive has been publicly emphasized by the Right Hon. Lord Greene, Master of the Rolls, as president of the British Record Association, as well as by other authorities.

The Council of the Newcomen Society directs attention to the corresponding need for watchfulness in the preservation by firms, public bodies and individuals, not only of documents but also of objects of enduring engineering and scientific interest. The Council had before it the case of the irreparable loss to Manchester of Richard Roberts's slide lathe of 1820 which was scrapped because "The lathe was very large and not complete [this was incorrect] and was seriously obstructing our work". A more recent attempt to scrap the contents of Wortley Iron Works near Sheffield, particularly two unique eighteenthcentury tilt hammers, has fortunately been averted by prompt action. Such danger of destruction is greatest when the salvagers are enthusiastic but illinformed persons.

The Council appeals for sufficient delay to get advice when in any doubt; there are several quarters that can give it, which the Society will be pleased to indicate if called upon.

Newcomen Society, 123 Riddlesdown Road, Purley, Surrey.

\section{E. Lancaster Burne} (President).

H. W. Dickinson (Hon. Sec). 